\title{
PENGARUH MENGKONSUMSI TEH SETELAH MAKAN TERHADAP KEJADIAN ANEMIA DEFISIENSI BESI PADA REMAJA PUTRI
}

\author{
Ida Royani ${ }^{1}$, Andi Alamanda Irwan ${ }^{2}$,dan Aridayanti Arifin ${ }^{3}$ \\ ${ }^{1}$ Bagian Gizi Fakultas Kedokteran Universitas Muslim Indonesia Makassar \\ ${ }^{2}$ Bagian Farmakologi Fakultas Kedokteran Universitas Muslim Indonesia Makassar \\ ${ }^{3}$ Mahasiswa Pre Klinik Fakultas Kedokteran Universitas Muslim Indonesia Makassar
}

Abstrak

Latar Belakang: Penelitian yang dilakukan di Amerika Serikat menyatakan bahwa kandungan tanin dan polifenol dalam teh dapat menghambat penyerapan zat besi dalam saluran cerna yang merupakan pemicu terjadinya anemia atau penyakit kurang darah. Karena zat tanin yang terdapat pada teh dapat mengikat zat besi pada makanan yang dicerna, sehingga membuat penyerapan zat besi atau Fe yang dilakukan oleh sel darah merah berkurang. Metode Penelitian: Desain penelitian ini adalah survei yang bersifat analitik yang dilakukan untuk mengetahui pengaruh mengkonsumsi teh setelah makan terhadap kejadian anemia pada remaja putri di Sekolah Putri Darul Istiqamah Kabupaten Maros. Rancangan yang digunakan adalah cross sectional. Analisis Bivariat yang digunakan yaitu dengan sistem komputerisasi melalui uji Chi-Square. Hasil Penelitian: Di Sekolah Putri Darul Istiqomah Kabupaten Maros remaja putri yang memiliki kebiasaan minum teh setelah makan secara rutin sebanyak 16 orang. Tidak ada responden yang memiliki riwayat anemia berat dari ke 16 responden sedangkan yang memiliki riwayat anemia sedang adalah 50\%, anemia ringan adalah $31,2 \%$, dan tidak anemia adalah 18,7\%. Kesimpulan: Terdapat pengaruh antara kebiasaan minum teh setelah makan terhadap kejadian anemia pada remaja putri di Sekolah Putri Darul Istiqamah Kabupaten Maros.

Kata Kunci: Anemia, Defisiensi Besi, Minum Teh.

\section{PENDAHULUAN}

Anemia secara fungsional didefinisikan sebagai penurunan jumlah massa eritrosit (red cell mast) sehingga tidak dapat memenuhi fungsinnya untuk membawa oksigen ke jaringan perifer dalam jumlah yang cukup (oxygen carryng capacity). ${ }^{1}$ 
Berdasarkan hasil Riset

Kesehatan Dasar (RISKESDAS) tahun 2013, didapatkan hasil prevalensi anemia pada remaja usia 15-24 tahun adalah 18,4\%. Hasil riset lain dari Bagian Kesehatan Ibu dan Anak Fakultas Kedokteran Universitas Diponegoro, Semarang membuktikan bahwa minum teh setelah makan dapat mengakibatkan terjadinya anemia. Dikarenakan minum teh paling tidak sejam sebelum atau setelah makan akan mengurangi daya serap sel darah terhadap zat besi sebesar $64 \% .^{4}$

Penelitian yang dilakukan oleh Cornell University dan The USDA's Agricultural Research Service (ARS). Ithaca, New York, Amerika Serikat menyatakan bahwa kandungan tanin dan polifenol dalam teh dapat menghambat penyerapan zat besi dalam saluran cerna yang merupakan pemicu terjadinya anemia atau penyakit kurang darah. Karena zat tanin yang terdapat pada teh dapat mengikat zat besi pada makanan yang dicerna, sehingga membuat penyerapan zat besi atau Fe yang dilakukan oleh sel darah merah berkurang. ${ }^{5}$
Berdasarkan uraian diatas, maka peneliti ingin mengetahui bagaimana pengaruh mengkonsumsi teh setelah makan terhadap kejadian anemia pada remaja putri di Sekolah Putri Darul Istiqamah Kabupaten Maros.

\section{METODE PENELITIAN}

Desain penelitian ini adalah survei yang bersifat analitik yang dilakukan untuk mengetahui pengaruh mengkonsumsi teh setelah makan terhadap kejadian anemia pada remaja putri di Sekolah Putri Darul Istiqamah Kabupaten Maros. Rancangan yang digunakan adalah cross sectional. Analisis Bivariat yang digunakan yaitu dengan sistem komputerisasi melalui uji Chi-Square.

Penelitian ini dilakukan di Sekolah Putri Darul Istiqamah yang beralamatkan di Jalan Poros MakassarMaros KM.25 Komp. City of Darul Istiqamah Maccopa Kabupaten Maros, Sulawesi Selatan. Penelitian dilakukan pada bulan Agustus 2017.

Populasi dalam penelitian ini adalah Semua remaja putri di Sekolah Putri Darul Istiqamah Kabupaten Maros SMP-IT kelas IX, SMA-IT kelas X, XI, dan XII yang 
berusia 15-18 tahun sejumlah 68 orang. Sampel dalam penelitian ini

\section{HASIL PENELITIAN}

Tabel 1. Hubungan Kebiasaan Minum Teh setelah Makan Terhadap Kejadian Anemia.

\begin{tabular}{|c|c|c|c|c|c|c|c|}
\hline \multirow{3}{*}{$\begin{array}{c}\text { Kebiasaan } \\
\text { Minum } \\
\text { Teh } \\
\text { Setelah } \\
\text { Makan }\end{array}$} & \multicolumn{4}{|c|}{ Kejadian Anemia } & \multirow{2}{*}{\multicolumn{2}{|c|}{ Total }} & \multirow{3}{*}{$\begin{array}{c}\text { Nilai } \\
\mathrm{P}\end{array}$} \\
\hline & \multicolumn{2}{|c|}{ Anemia } & \multicolumn{2}{|c|}{$\begin{array}{r}\text { Tidak } \\
\text { Anemia }\end{array}$} & & & \\
\hline & $\mathrm{N}$ & $\%$ & $\mathrm{~N}$ & $\%$ & $\mathrm{~N}$ & $\%$ & \\
\hline $\begin{array}{c}\text { Beresiko } \\
\text { Anemia }\end{array}$ & 13 & $27,1 \%$ & 3 & $6,3 \%$ & 16 & $33,3 \%$ & \\
\hline $\begin{array}{c}\text { Tidak } \\
\text { Beresiko } \\
\text { Anemi }\end{array}$ & 0 & $0,0 \%$ & 32 & $66,7 \%$ & 32 & $66,7 \%$ & 0,000 \\
\hline Total & 13 & $27,1 \%$ & 35 & $72,9 \%$ & 48 & $100 \%$ & \\
\hline Sumber: $D c$ & & diolah & & $P S S 2$ & 017 & & \\
\hline
\end{tabular}

menunjukkan bahwa responden yang memiliki kebiasaan minum teh setelah makan > 5 cangkir teh berukuran $200 \mathrm{ml}$ dalam sehari dengan rentan waktu minum teh $\leq 1$ jam setelah makan (Beresiko Anemia) yang memiliki riwayat anemia sebanyak 13 orang dengan perentase $(27,1 \%)$ dan yang tidak memiliki riwayat anemia sebanyak 3 orang dengan persentase $(6,3 \%)$. Sedangkan responden yang memiliki kebiasaan minum teh setelah makan $\leq 5$ cangkir teh berukuran $200 \mathrm{ml}$ dalam sehari dengan waktu minum teh > 1,5 sampai 2 jam setelah makan (Tidak Beresiko Anemia) tidak ada yang memiliki riwayat diambil dengan menggunakan metode total sampling.

anemia $(0,0 \%)$ sedangkan responden yang tanpa riwayat anemia sebanyak 32 orang dengan persentase $(66,7 \%)$.

\section{PEMBAHASAN}

Berdasarkan hasil penelitian diketahui bahwa remaja putri di Sekolah Putri Darul Istiqamah Kabupaten Maros yang memiliki kebiasaan minum teh setelah makan (Beresiko Anemia) yang memiliki riwayat anemia sebanyak 13 responden $(27,1 \%)$ menunjukkan bahwa terdapat pengaruh kebiasaan minum teh setelah makan terhadap kejadian anemia defisiensi besi pada remaja putri di Sekolah Putri Darul Istiqamah Kabupaten Maros.

Penyerapan zat besi sangat dipengaruhi oleh kombinasi makanan yang diserap pada waktu makan makanan tertentu, terutama teh kental yang akan menimbulkan penghambatan nyata pada penyerapan zat besi (Soehardi,2004). Senyawa tanin dari teh yang berlebihan dalam darah akan mengganggu penyerapan zat besi. Tubuh kekurangan zat besi maka 
pembentukan butir darah merah (hemoglobin) berkurang sehingga mengakibatkan anemia. Pengaruh penghambatan tanin dapat dihindarkan dengan cara tidak minum satu jam setelah makan karena dapat menurunkan absorbsi zat besi hingga $85 \%$.

Hasil penelitian ini sejalan dengan teori Septiawan (2015) bahwa tanin merupakan polifenol yang terdapat didalam teh, kopi dan beberapa jenis sayuran serta buah yang juga dapat menghambat absorbsi besi dengan cara mengikat besi. Bila $\mathrm{Fe}$ dalam tubuh tidak terlalu tinggi, sebaiknya tidak mengkonsumsi teh pada waktu makan.

\section{KESIMPULAN}

Karena hasil penelitian menunjukkan terdapat hubungan yang signifikan, maka dengan ini dapat dinyatakan bahwa semakin banyak frekuensi konsumsi teh yang diminum serta jarak waktu yang dekat antara konsumsi teh setelah makan yang rutin dilakukan maka resiko kejadian anemia semakin tinggi.

\section{DAFTAR PUSTAKA}

1. World Health Organization. Global Nutrition targets 2025.

Anaemia

PolicyBrief(www.who.int/nut rition/topics/nutritionglobaltar gets2025/en/,a ccessed 6 November 2016).

2. Kalsum, Ummi. Raden, 2016. Kebiasaan sarapan pagi berhubungan dengan kejadian Anemia pada Remaja di SMA Negeri 8 Muaro Jambi. Volume 18, Nomor 1, Hal 09-19. Skripsi: FKM Universitas Jambi.

3. Depkes RI 2003. "Program

Penanggulangan Anemia Gizi

Pada Wanita

Usia Subur (WUS)."

www.depkes.go.id diakses pada 29 Januari 2017.

4. Peraturan Menteri Kesehatan R.I, 2013. Angka Kecukupan Gizi yang DianjurkanBagiBangsaIndon esia.www.hukor.depkes.go.id lup_prod_perm enkes/PMK.No.75 diakses pada 28 Januari 2017.

5. Almatsier, S. 2009. Prinsip Dasar Ilmu Gizi. Jakarta: Gramedia Pustaka Utama.

6. Besral, Meilianingsih L, Sahar J, 2007. Pengaruh Minum Teh terhadap Kejadian Anemia pada Usila di Kota Bandung. Makara, Kesehatan, Vol. 11, No. 1: 38-43.

7. Silaban, M. 2005. Pengaruh Jenis Teh dan Lama Fermentasi pada Proses Pembuatan The Kombucha. USU Repository : Skripsi FP USU. 
8. Jurnal Al-Azhar Indonesia Seri Sains dan Teknologi, Vol. 2, No. 2, September 2013.

9. Hafifah Nurul C, 2016. Amankah Anak Anda Mengkonsumsi Teh? (http://www.idai.or.id/artikel/ klinik/pengasuhananak/amankah-anak-andamengkonsumsi-teh accessed 28 Desember 2016).

10. Fragcana Putra, 2015. Efek Samping Teh Setelah Makan. Papuan Youth Health. Diakses pada 5 Januari 2017.

11. Kementerian Kesehatan Republik Indonesia. 2015. Pekerja Perempuan Rentan terhadap Anemia Gizi. Diakses pada 5 Desember 2016.

12. Proverewati, A, \& Asfuah, S. 2009. Gizi untuk Kebidanan. Yogyakarta: MuhaMedika.

13. Irianto dan Waluyo.K 2004. Gizi dan Pola Hidup Sehat. Bandung: CV. Yrama Widya.

14. Aulia, 2012. Serangan Penyakit-Penyakit Khas Wanita Paling Sering Terjadi. Yogyakarta : Buku Biru

15. Bakta, I Made, 2013. Hematologi Klinik Ringkas. Jakarta: EGC, Hal. 26-34.

16. Dedeh, dkk. 2010. Sehat dan Bugar Berkat Guzu Seimbang. Jakarta: Penerbit PT Sarana Bobo.

17. De Benoist et al., eds. 2008. Worldwide prevelence of anemia 1993-2005. WHO Global Database on Anaemia Geneva: World Health Organization,

18. Emma B, Zulhaida L, Albiner S. 2012. Perilaku Minum Teh dan Kadar Hemoglobin ( $\mathrm{Hb}$ ) pada Siswa-siswi Sekolah Menengah Kejuruan Negeri 1 Jorlang Hataran Desa Dolok Marlawan Kecamatan Jorlang Kabupaten Simalungun Tahun 2012. Skripsi: FKM USU

19. Jurnal Sains dan Teknologi Nuklir Indonesia Indonesian Journal of Nuclear Science and Technology Vol. X, No. 2, Agustus 2009: 71-80

20. Patimah, Sitti.,Ida, Royani., Ansar Mursaha.,Abdul Razak Thaha. 2015. Knowledge, Attitude and Practice of Balanced Diet and Correlation with Hypochromic Microcyctic Anemia among Adolescent School Girls in Maros District, South Sulawesi, Indonesia. An International Jurnal of Medical Sciences. Biomedical Research

21. Proverewati, A, \& Misaroh, S. 2009. Menarche (Menstruasi Pertama Penuh Makna). Yogyakarta : Muha Medika

22. Giyanti, Fitri, 2016. Pengarh Pemberian Tablet FE terhadap Kenaikan Kadar $\mathrm{Hb}$ Remaja Putri dengan Anemia di SMK Negeri 1 Ponjong Gunung Kidul. Skripsi: Fakultas Ilmu Kesehatan Universitas Aisyiah Yogyakarta.

23. Rahman, S. 2016. Hubungan Kebiasaan Minum Teh dan Pengetahuan Gizi dengan Kadar Hemoglobin pada siswi di SMK Negeri 1 Sukoharjo Kabupaten Sukoharjo. Surakarta: Skripsi FIK UMS.

24. Sasongko, cahyo 2016. Hubungan Antara 
Pengetahuan dan Perilaku Minum Teh/Kopi dengan Kejadian Anemia pada Siswi di SMA Takhassus Al-Qur'an Kalibeber Wonosobo. Skripsi : Fakultas Kesehatan Masyarakat Sekolah Tinggi Ilmu Kesehatan Ngudi Waluyo Ungaran.

25. Satgas, 2013. Nutrisi pada Remaja

(http://www.idai.or.id/artikel/ seputar-kesehatan- anak/nutrisi-pada-remaja accessed 28 Desember 2016)

26. Sediaoetama, A.D. 2003. Ilmu Gizi untuk Mahasiswa dan Profesi di Indonesia Jilid I,II,III Jakarta: Penerbit Dian Rakyat.

27. Setiati S, Alwi I, Sudoyo, 2014. Buku Ajar Ilmu Penyakit Dalam. Jakarta, InternalPublishing Edisi 6. Vol. II, Hal.2589. 